\title{
IN THE UNITED STATES PATENT AND TRADEMARK OFFICE
}

PATENT NO.: $\quad 7,029,913$

ISSUED: $\quad$ April 18, 2006

TO: $\quad$ Thomson

FOR: $\quad$ PRIMATE EMBRYONIC STEM CELLS

ATTACHMENT TO FORM PTO-1465, REQUEST FOR INTER PARTES REEXAMINATION

SIR:

On behalf of the Foundation for Taxpayer and Consumer Rights ("FTCR"), a nationally recognized not-for-profit organization that represents the interests of taxpayers and consumers, the Public Patent Foundation ("PUBPAT") respectfully requests inter partes reexamination under 35 U.S.C. $\S \S 311-318$ and 37 C.F.R. $\S 1.913$ of every claim of United States Patent No. 7,029,913 ("the '913 patent") issued April 18, 2006, to Thomson because they are all invalid under 35 U.S.C. $\S 103$ and their existence is causing significant public harm. ${ }^{1}$ FTCR, the real party in interest, hereby certifies that the estoppel provisions of 37 C.F.R. $§ 1.907$ do not prohibit this request for inter partes reexamination.

1 A copy of the '913 patent is attached hereto as Appendix A. 


\section{THE '913 PATENT IS CAUSING SIGNIFICANT PUBLIC HARM}

Human embryonic stem ("ES") cell research possesses great promise to be the next frontier of medical advance. Scientists already believe that human ES cell research will produce new ways of not just treating, but preventing, a wide range of diseases, including AIDS, diabetes, Parkinson's, Alzheimer's and heart disease. Although the federal government has limited its funding of human ES cell research, many states, including most notably California which created a $\$ 3$ billion state taxpayer-funded institute for stem cell research in November 2004, have chosen to provide the support that is needed to foster such research here in America.

To achieve the promise of human ES research, however, scientists need to not only be funded, they also need to be free of unjustified restraints on their work. Unfortunately, human ES cell researchers are currently being restrained by the '913 patent and two other related patents, U.S. Patents Nos. 5,843,780 ("the '780 patent") and 6,200,806 ("the '806 patent"). These three patents, which broadly claim any primate or human ES cell, are being widely and aggressively asserted be their owner against every human ES cell researcher in the United States. Licensing Fees Slow Advance of Stem Cells, Nature 435:272 (May 19, 2005).

By demanding significant financial consideration before allowing research to be performed, the owner of the '913, '780 and '806 patents is impeding, and in some cases literally stopping, domestic human ES cell research at its infancy. Id. This not only harms scientific advance here in the United States, it also has a harmful economic impact on Americans by diverting taxpayer dollars meant for research to pay for licensing fees. In the words of one 
industry insider, this aggressive patent assertion is "stifling industrial research and investment." Id.

Although these scientific and economic concerns are admittedly not grounds to grant this request for reexamination, FTCR respectfully requests that they be considered when determining whether questions regarding the validity of the '913 patent merit review by your office. As set forth more fully below, FTCR believes that the '913 patent is invalid and, as such, should be eliminated as an impediment to American human ES cell research.

\section{THE SUBSTANTIAL NEW OUESTIONS OF PATENTABILITY}

The substantial new questions of patentability raised by this request are whether all 3 claims of the '913 patent were obvious in light of Robertson, et al., "Isolation, Properties and Karyotype Analysis of Pluripotential (EK) Cell Lines From Normal and Parthenogenetic Embryos," Teratocarcinoma Stem Cells, Cold Spring Harbor Laboratory, Cold Spring Harbor, 10:647-663 (1983) (“Robertson 1983”), Robertson, Elizabeth J., "Embryo-Derived Stem Cell Lines," Teratocarcinomas and Embryonic Stem Cells; A Practical Approach, Oxford: 1RL Press, Ch. 4:71-112 (1987) ("Robertson 1987") and Piedrahita, et al., "On The Isolation Embryonic Stem Cells: Comparative Behavior Of Murine, Porcine And Ovine Embryos," Theriogenology, 34(5):879-901 (1990) (“Piedrahita"), either separately or when viewed together. ${ }^{2}$

These are substantial new questions of patentability because neither Robertson 1983 nor Robertson 1987 was of record during prosecution of the '913 patent and Piedrahita was not of record during prosecution of the instant application that led to the '913 patent. A detailed

2 Copies of Robertson 1983, Robertson 1987 and Piedrahita are attached hereto as Appendix B. 
explanation of the pertinency and manner of applying Robertson 1983, Robertson 1987 and Piedrahita to every claim of the '913 patent is set forth below.

\section{ROBERTSON 1983, ROBERTSON 1987 AND PEIDRHITA, EITHER SEPARATELY OR TOGETHER, RENDERED OBVIOUS THE CLAIMS OF THE '913 PATENT}

Robertson 1983 was published in 1983, Robertson 1987 was published in 1987 and Piedrahita was published in 1990. The earliest application to which the '913 patent claims priority was filed January 20, 1995, more than a year after Robertson 1983, Robertson 1987 and Piedrahita were each published. Therefore, Robertson 1983, Robertson 1987 and Piedrahita are each prior art to the '913 patent under 35 U.S.C. $\S 102(b)$.

\section{Robertson 1983 and Robertson 1987 Rendered the '913 Patent Obvious}

More than a decade before the initial application leading to the '913 patent was filed, Robertson 1983 taught a step-by-step process for isolating pluripotential mammalian ES cells. Robertson 1983's process included the steps of: (i) isolating a blastocyst, (ii) removing the ICM from the blastocyst, (iii) placing the ICM on fibroblast cells, (iv) isolating stem cells once they became apparent, and (v) maintaining the isolated ES cells on feeder layers. Robertson 1983 at 649. Robertson 1983's ES cells were pluripotential, were maintained over a significant time period and retained a normal euploid karyotype. Id. at 647, 654 and 660 ("the B2B2 line has now been shown to retain normal XY karyotype after more than 45 passage generations").

A few years later, Robertson 1987 again taught the step-by-step process for isolating pluripotential mammalian ES cells, this time giving even further detail regarding each specific step. For example, Robertson 1987 gives highly technical instruction on preparing feeder 
layers, collecting blastocyst stage embryos, transferring the embryos into culture, culturing the blastocysts, disaggregating the ICM, identifying ICM-derived colonies, expanding ES cells and culturing ES cells. Robertson 1987 at 76-94. Since Robertson 1983 and Robertson 1987 were penned by the same person and since Robertson 1987 expressly cites Robertson 1983, one of ordinary skill in the art would have been motivated to combine their teachings. Robertson 1987 at 112 (citing Robertson 1983).

The '913 patent contains only 3 claims, which read:

1. A replicating in vitro cell culture of human embryonic stem cells comprising cells which (i) are capable of proliferation in in vitro culture for over one year without the application of exogenous leukemia inhibitory factor, (ii) maintain a karyotype in which the chromosomes are euploid through prolonged culture, (iii) maintain the potential to differentiate to derivatives of endoderm, mesoderm, and ectoderm tissues throughout the culture, and (iv) are inhibited from differentiation when cultured on a fibroblast feeder layer.

2. The preparation of claim 1, wherein the stem cells will spontaneously differentiate to trophoblast and produce chorionic gonadotropin when cultured to high density.

3. The preparation of claim 1 wherein the cells are negative for the SSEA-1 marker, positive for the SSEA-4 marker, and express alkaline phosphatase.

'913 patent, 21:21 - 22:27.

The only difference between Robertson 1983 and Robertson 1987 and the claims of the '913 patent is that Robertson 1983 and Robertson 1987 isolate mouse ES cells while the '913 patent claims human ES cells. However, Dr. Jeanne F. Loring, a leading research embryologist at the Burnham Institute in La Jolla, California, who was directing ES cell research and specifically focusing on derivation of novel ES cell lines at the time the earliest priority 
application for the '913 patent was filed, states in the attached declaration that,

[A]t the time the first application leading to the '913 patent was filed, it was obvious to one of ordinary skill in the art of ES cell derivation that the process taught by Robertson 1983 and Robertson 1987 for isolating mouse ES cells could be used to isolate ES cells of other mammals, including humans as claimed in the '913 patent, with a reasonable expectation of success.

Declaration of Dr. Jeanne F. Loring, p. 3. ${ }^{3}$ In support of her opinion, Dr. Loring cites several conversations she had with other stem cell scientists prior to January 20, 1995, regarding how Robertson's method for deriving mouse ES cells could also be used to isolate human ES cells. Id. at 5-7. As such, Robertson 1983 and Robertson 1987 rendered each of the claims of the '913 patent invalid because they were no more than obvious implementations of Robertson's method.

With respect to those elements of the '913 patent's claims not found expressly in Robertson 1983 and Robertson 1987 - such as producing chronic gonadotropin when cultured to high density, being negative for the SSEA-1 marker and positive for the SSEA-4 marker and expressing alkaline phosphate - they are all attributes that the '913 patent concedes are inherent to human ES cells. '913 patent, 2:44-47 (“" [c]horionic gonadotropin, expressed by the trophoblast, is ... in all primates, including humans"), 4:26-28 ("primate ES cell lines are preferably negative for the SSEA-1 marker $\ldots$ and positive for the SSEA-4 marker"), 10:65-66 ("[a]lkaline phosphatase will also be present on all primate ES cells"), and 17:48-52 ("a series of cell surface markers (alkaline phosphatase, SSEA-3, SSEA-4, TRA-1-60, and TRA-1-81) ... are definitive markers for ... primate ES cells"). Therefore, those claim limitations provide no unobvious difference over Robertson 1983 and Robertson 1987.

3 The Declaration of Dr. Jeanne F. Loring, Ph.D. is attached hereto as Appendix C. 
Although the '913 patent goes to great lengths to explain why human ES cells are more important and more beneficial for scientific research than mouse ES cells, it does not sufficiently address why a well known method for isolating mouse ES cells would not also work to isolate human ES cells. In fact, the method of isolating ES cells described in the '913 patent is the exact same process taught by Robertson 1983 and Robertson 1987 more than a decade earlier. '913 patent, 4:46-56. Thus, any argument that the process taught by Robertson 1983 and Robertson 1987 would not have been expected to work for humans is belied by the fact that the '913 patent - in fact - concedes that it did.

Further, there is no evidence of any (i) teaching away from using Robertson 1983's and Robertson 1987's method to isolate human ES cells or (ii) failure of others to isolate human ES cells using Robertson 1983's and Robertson 1987's method. To the contrary, other persons with ordinary skill in the art recognized that " $[\mathrm{t}]$ he development of mouse ES cells in 1981 provided the paradigm, and, much of the technology, for the development of human ES cells." U.S. Patent No. 6,875,607, 1:26-29. Thus, all of these secondary considerations further support the conclusion that the '913 patent was obvious in light of Robertson 1983 and Robertson 1987.

\section{Piedrahita Alone Rendered the '913 Patent Obvious}

Piedrahita taught a method of isolating murine (rodent), porcine (pig) and ovine (sheep) ES cells. Piedrahita at 882-883. The blastocysts were isolated and then the cells from the ICM were isolated. The ICM was then placed on an embryonic fibroblast feeder layer (Piedrahita taught the use of both STO and HEF feeder layers). After plating, the growing ICM was dissociated and replated onto fresh feeder layer. ES cells were then selected based on a large 
nucleus and prominent nucleoli. These selected cells were then cultured on fresh feeder layer in order to prevent differentiation. Piedrahita's ES cells were pluripotential, were maintained over a significant time period and retained a normal euploid karyotype. Id. at 883-884 and 888 ("maintained for 42 passages with no sign of decreased growth rate or obvious morphological changes").

The only difference between Piedrahita and the claims of the '913 patent is that Piedrahita isolated murine, porcine and ovine ES cells while the '913 patent claims human ES cells. However, Dr. Loring states in the attached declaration that,

[A]t the time the first application leading to the '913 patent was filed, it was obvious to one of ordinary skill in the art of ES cell derivation that the process taught by Piedrahita for isolating murine, porcine and ovine ES cells could be used to isolate ES cells of other mammals, including humans as claimed in the '913 patent, with a reasonable expectation of success.

Declaration of Dr. Jeanne F. Loring, p. 4. As such, Piedrahita rendered each of the claims of the '913 patent invalid because they were no more than obvious implementations of Piedrahita's method.

With respect to those elements of the '913 patent's claims not found expressly in Piedrahita - such as producing chronic gonadotropin when cultured to high density, being negative for the SSEA-1 marker and positive for the SSEA-4 marker and expressing alkaline phosphate - they are all attributes that the '913 patent concedes are inherent to human ES cells. '913 patent, 2:44-47 ("[c]horionic gonadotropin, expressed by the trophoblast, is ... in all primates, including humans"), 4:26-28 ("primate ES cell lines are preferably negative for the 
SSEA-1 marker ... and positive for the SSEA-4 marker"), 10:65-66 ("[a]lkaline phosphatase will also be present on all primate ES cells"), and 17:48-52 ("a series of cell surface markers (alkaline phosphatase, SSEA-3, SSEA-4, TRA-1-60, and TRA-1-81) $\ldots$ are definitive markers for ... primate ES cells"). Therefore, those claim limitations provide no unobvious difference over Piedrahita.

Although the '913 patent concedes that, "[p]luripotent cell lines have also been derived from preimplantation embryos of several domestic and laboratory animals species," it argues that "[w]hether or not these cell lines are true ES cells lines is a subject about which there may be some difference of opinion" and that "[s]trong evidence of these required properties have been published only for rodents ES cells." 3:50 - 4:13. However, the '913 patent fails to mention the "strong evidence" of Piedrahita that leaves no "difference of opinion" regarding its teaching of pluripotent ES cells of mammals other than rodents.

In fact, the method of isolating ES cells described in the '913 patent is the exact same process taught by Piedrahita several years earlier. '913 patent, 4:46-56. Thus, any argument that the process taught by Piedrahita would not have been expected to work for humans is belied by the fact that the ' 913 patent - in fact - concedes that it did. Further, there is no evidence of any (i) teaching away from using Piedrahita's method to isolate human ES cells or (ii) failure of others to isolate human ES cells using Piedrahita's method. Thus, these secondary considerations further support the conclusion that the '913 patent was obvious in light of Piedrahita. 
It should be noted that during prosecution of one of the '913 patent's parent applications, U.S. Patent Application No. 08/376,327 ("the '327 application"), the Examiner applied Piedrahita in rejecting the then pending claims. Office Action, January 17, 1996, p. 5. In making the rejection, the Examiner stated,

The only apparent difference between the method of Piedrahata [sic] et al. and that of the instant claims is that the claims isolate primate ES cells whereas Piedrahata [sic] et al. isolates murine, porcine and ovine ES cells. However, one of ordinary skill in the art would have a reasonable expectation of success in isolating primate ES using the same method taught by Piedrahata [sic] et al for isolating murine, porcine or ovine ES cells.

Id. at $6{ }^{4}$

The applicant responded to the Piedrahita rejection by arguing that "persons of high skill in the art still do not believe that they can predict whether methods worked out in one species will or will not work in another distantly-related species" and that "work from mice or sheep does not provide sufficient guidance, in this art, to demonstrate a reasonable expectation of success in primates." Amendment, July 23, 1996, pp. 6-7. ${ }^{5}$ However, those conclusory arguments were completely unsupported with any evidence and correctly found unpersuasive by the Examiner, who responded to applicant's arguments by making the Piedrahita rejection final and stating that,

... the method of Piedrahata [sic] is identical to the claimed process with the exception of the source of the cells. The reference has applied the method to murine, porcine and ovine animals, three diverse categories of mammals and therefore the method could be applied to other mammals such as primates with a reasonable expectation of success.

4 A copy of the January 17, 1996, Office Action is attached hereto as Appendix D.

5 A copy of the July 23, 1996, Amendment is attached hereto as Appendix E. 
Office Action, October 28, 1996, p. $4 .{ }^{6}$

In the face of the final rejection, the applicant abandoned the '327 application and shifted prosecution to a continuation-in-part application. The instant application leading to the '913 patent was a related application descending from a line of continuations and a divisional of the '327 application, but Piedrahita was never discussed during the prosecution of any of those other applications. In fact, Piedrahita was never cited or made of record by the applicant in the instant application leading to the '913 patent, despite the fact that the applicant obviously knew of its existence and that the Examiner of the initial ' 327 application found it to be highly material. Thus, the rejection made in the ' 327 application based on Piedrahita was never overcome by the applicant and remains a valid basis of rejection of the '913 patent's claims.

\section{Robertson 1983, Robertson 1987 and Piedrahita Together Rendered the '913 Patent Obvious}

The combined teachings of Robertson 1983, Robertson 1987 and Piedrahita further render the '913 patent obvious because they use virtually the same process to isolate ES cells of several different mammalian species. Dr. Loring states in the attached declaration that,

[A]t the time the first application leading to the '913 patent was filed, it was obvious to one of ordinary skill in the art of ES cell derivation that the process taught by Robertson 1983, Robertson 1987 and Piedrahita for isolating mouse, murine, porcine and ovine ES cells could be used to isolate ES cells of other mammals, including humans as claimed in the '913 patent, with a reasonable expectation of success.

Declaration of Dr. Jeanne F. Loring, p. 5. Thus, since the same process was known, at the time the earliest claimed priority application for the '913 patent was filed, to work to isolate various

6 A copy of the October 28, 1996, Office Action is attached hereto as Appendix F. 
types of mammalian ES cells, one of ordinary skill in the art would have expected the process to work for human ES cells as well because humans are yet another type of mammal and are no more different from mice, rats, pigs, and sheep than they are each from each other.

One of ordinary skill in the art would have been motivated to combine the teachings of Robertson 1983, Robertson 1987 and Piedrahita because they are directed to exactly the same field of scientific endeavor, namely the isolation of mammalian ES cells. In addition, Robertson 1987 was written by the same author as Robertson 1983 and Robertson 1987 and Piedrahita both expressly cited Robertson 1983, thus incorporating it by reference. Robertson 1987 at 112 (citing Robertson 1983); Piedrahita at 900 (citing Robertson 1983). As such, when viewed together, Robertson 1983, Robertson 1987 and Piedrahita render each of the claims of the '913 patent invalid because it would have been obvious that the method described in those references for isolating ES cells of several different mammalian species could be expected to work to isolate human ES cells as well.

[continued on next page] 


\section{CONCLUSION}

For the reasons set forth above, each of the claims of the ' 913 patent are invalid for being obvious in light of Robertson 1983, Robertson 1987 and Piedrahita. As such, PUBPAT, on behalf of FTCR, respectfully requests that they be reexamined inter partes and ultimately canceled.

Date

Daniel B. Ravicher, Esq.

U.S.P.T.O. Reg. No. 47,015

PUBLIC PATENT FOUNDATION, INC.

1375 Broadway, Suite 600

New York, NY 10018

Tel: (212) 545-5337

Fax: (212) 591-6038

www.pubpat.org

Attorneys for the Foundation for Taxpayer and Consumer Rights 